\title{
Epidemiologic and Clinical Differences Between Classic and Hypertrophic Lichen Planus in Nigeria
}

\author{
Okpala CHIBUZOR IFEANYI ${ }^{1}$, Adeolu OLADAYO AKINBORO², Ifeanyi OGOCHUKWU EZE- \\ JOIFOR $^{3}$, Abel N. ONUNU ${ }^{4}$ and Benson UCHECHUKWU OKWARA ${ }^{4}$ \\ ${ }^{1}$ Dermatology Unit, Department of Medicine, Nnamdi Azikiwe University Teaching Hospital, Nnewi, Anambra State Nigeria. \\ ${ }^{2}$ Dermatology Unit, Department of Internal Medicine, Ladoke Akintola University of Technology, Ogbomoso and LAU- \\ TECH Teaching Hospital, Ogbomoso, Oyo State, Nigeria \\ ${ }^{3}$ Dermatology Unit, Department of Medicine, Nnamdi Azikiwe University Nnewi Campus, Anambra State Nigeria. \\ ${ }^{4}$ University of Benin and University of Benin Teaching Hospital, Edo State, Nigeria
}

*Correspondence: Adeolu Oladayo Akinboro, E-mail: deolusteve111@yahoo.com

UDC 616.516-036.22(669)

\begin{abstract}
Introduction. Lichen planus is a chronic inflammatory skin disease known to have several clinical variants with attended variable clinical outcomes. Certain complications have been observed in the hypertrophic type, which were not found in association with the classic variant. Objective: To identify the epidemiologic and clinical differences between the classic and hypertrophic lichen planus and clinical correlates. Material and Methods. Of 104 participants with lichen planus included in the study, 49 had classic and 55 hypertrophic lichen planus. Demographic and clinical information was obtained. Diagnosis of lichen planus was made clinically and confirmed with histology. The participants were screened for metabolic syndrome, hepatitis B, and C. Results: Mean age of all patients was $37.20 \pm 13.39$ years, with no age and gender differences between the participants with classic and hypertrophic lichen planus. Classic lichen planus was more likely to be painful, ( $8.2 \%$ vs $0.0, p=0.046)$, generalized $(95.9 \%$ vs $16.4 \%, p<0.001)$, involve the oral mucosa $(38.8 \%$ vs $0.0, p<0.001)$, the nails $(38.8 \%$ vs $1.8, p<0.001)$, present with kobnerisation $(55.1 \%$ vs $5.5 \%,<0.001)$, Wickhiam striae $(69.4 \%$ vs $16.4 \%, p<0.001)$, associated with Hepatitis B vaccination (16.3\% vs $3.6 \%, p<0.028)$ and anti HCV positivity $(16.3 \%$ vs $0.0 \%, p=0.002)$. Hypertrophic lichen planus was significantly associated with impaired glucose tolerance/diabetes mellitus $(16.4 \%$ vs $2.0 \%$, $\mathrm{p}=0.013)$, dyslipidemia $(74.5 \%$ vs $40.8 \%, p=0.001)$ and saw- tooth histologic appearance compared to classic type. Conclusion: Hypertrophic lichen planus is more likely to be associated with metabolic complications compared to the classic type. Further studies are needed to loink this difference t chronic inflamation.
\end{abstract}

Key words: Lichen Planus; Comorbidity; Signs and Symptoms; Lichen Planus, Oral, Diabetes Mellitus; Diagnosis; Epidemiologic Studies; Nigeria

\section{Introduction}

Lichen planus (LP) is an idiopathic, inflammatory skin disease with unique clinical and histologic features (1-3). The LP commonly affects the skin and the mucous membrane but may also affect the nails and hair (1-3). Clinically, the classic LP is characterized by scaly, flat-topped, polygonal, shining and violaceous papules with reticular, lacy, white lines known as Wickham's striae; however, these papules may appear bluish-grey in individuals with dark skin (1-3). Lichen planus lesions may appear linearly, following the lines of trauma referred to as Koebner phe- nomenon (4); other variants of LP may include annular LP, atrophic LP, hypertrophic LP, vesiculobullous LP, erosive/ulcerative LP, LP pigmentosus, and lichen planopilaris. Other nomenclature of LP includes mucosal LP, nail LP, inverse LP, LP pemphigoides, lichen planus-lupus erythematosus overlap syndrome and drug-induced LP (1-5).

Classic LP (CLP) typically presents with the four P's: purplish, pruritus, polygonal, and papules and/or plaques. It is usually symmetric, and it favors flexural surfaces, sacral region, and oral mucosa; the scalp, hair, nails, and other mucosal surfaces could be involved 
as well but the face is typically spared (1-3, $5,6)$. The hypertrophic type of LP (HLP), however, is a distinct type of LP that presents with pruritic hyperpigmented thickened papules and plaques with a preference for the pretibial area of the lower extremities and the ankles (1-7). Typically, HLP is more chronic and pruritic and could rarely become generalized $(7$, 8). HLP could also infrequently become a disseminated disease (8). The etiology of HLP has been related to the eosinophils (9) and Koebner phenomenon (5). In recent time, HLP has been associated or called a mimicker of squamous cell carcinoma (10-12).

Few Nigerian studies have detailed the epidemiology of LP (13-17), but none has examined the differences or peculiarities of CLP and HLP. The main aim of this study is to research into any existing demographic, clinical and histologic differences between CLP and HLP and to determine the clinical correlates of both types of LP among patients attending the Dermatology Clinics of two Nigerian Teaching Hospitals located in southeastern and southwestern Nigeria.

\section{Methodology}

This cross-sectional study was conducted at the Dermatology Clinics of Nnamdi Azikiwe Teaching Hospital, Nnewi and LAUTECH Teaching Hospital, (LTH), Ogbomoso, Nigeria between December 2014 and February 2016. The study population consisted of 104 patients with CLP and HLP. The diagnosis of LP was made clinically and confirmed by histology via skin biopsies obtained from a fresh lesion. According to the inclusion criteria the sample included adult patients with clinical presentation in keeping with classic and hypertrophic types of LP and confirmed by histology. The patients below the age of 18 years, other variants of LP and those with history and clinical features suggestive of lichenoid drug eruptions and other types of LP were excluded. Ethical approval for the study was obtained from the ethical committee of Nnamdi Azikiwe and LAUTECH Teaching Hospitals and informed written consent was taken from all the patients before they were included in the study.

Data of all participants were obtained using an interview-administered questionnaire. The data collected included sociodemo- graphic characteristics such as age, gender, occupation, marital status, and educational level attained. The survey also included the clinical history such as pruritus, pain, previous episode of LP, site of onset, treatment sought, smoking and alcohol intake. We asked for a family history of similar disease, hypertension, diabetes mellitus, and cardiovascular events.

Physical examination: The entire skin, hair, nails, and the mucous membrane were examined in bright daylight. The morphology, arrangement, distribution, and site of the lesions were documented. Wickham striae were examined after the application of mineral oil using the hand-held dermoscopy (RA Bock Diagnostic Pro-Physician 3.5V Dermatolight -LED) to observe the presence of Wickham striae. Other clinical signs, such as the Kobner phenomenon, were noted.

A localized lesion was defined as a LP lesion restricted to a portion of the skin while the generalized cutaneous LP disease was defined as the involvement of the skin of the trunk, the upper and the lower limbs. The participants' body weight was examined using a weighing scale, height was assessed using clinic stadiometer, and body mass index (BMI) was calculated using the formulae weight/ height squared.

Laboratory: twelve milliliters of venous blood were collected after 12 hour overnight fasting, twelve milliliters of venous blood were collected from a vein in the antecubital fossa. Serum samples were sent for the detection of anti-hepatitis $\mathrm{C}$ virus (HCV) antibody, hepatitis $B$ virus surface antigen ( $\mathrm{HBsAg})$, fasting lipid profile [total cholesterol, high-density lipoprotein cholesterol (HDL-c), low-density lipoprotein (LDL-C) and triglyceride], and fasting blood glucose using standard methods (18-22). The diagnosis of the metabolic syndrome and dyslipidemia was based on the National Cholesterol Education Program Adult Treatment Panel III working definition (23). Skin biopsy was performed in the consulting room after obtaining consent using an appropriate size punch biopsy needle. The samples were sent to the histopathology laboratory of NAUTH and LAUTECH Teaching Hospital for histology. 
Table 1. Sociodemographic Characteristics of Lichen Planus Patients

\begin{tabular}{lcccc} 
Characteristics of Lichen Planus & Total & $\begin{array}{c}\text { Classic LP } \\
\mathbf{N}=\mathbf{4 9}\end{array}$ & $\begin{array}{c}\text { Hypertrophic LP } \\
\mathbf{N}=\mathbf{5 5}\end{array}$ & p-value \\
Mean age (years) $\pm \mathrm{SD}$ & $37.20 \pm 13.39$ & $35.47 \pm 12.32$ & $38.75 \pm 14.21$ & 0.215 \\
\hline Gender & $55(52.9)$ & $26(53.1)$ & $29(52.7)$ & 0.973 \\
\hline Male & $49(47.1)$ & $23(46.9)$ & $26(47.3)$ & \\
Female & & & & \\
\hline Occupation & $29(27.9)$ & $13(26.5)$ & $16(29.1)$ & 0.023 \\
\hline Civil Servant & $32(30.8)$ & $14(28.6)$ & $18(32.7)$ & \\
Trading & $5(4.8)$ & $5(10.2)$ & $0(0.0)$ & \\
Clergy & $4(3.8)$ & $1(2.0)$ & $3(5.5)$ & \\
Schooling & $2(1.9)$ & $2(4.1)$ & $0(0.0)$ & \\
Artisan & $27(26.0)$ & $14(28.6)$ & $13(23.6)$ & \\
Unemployed & $5(4.8)$ & $0(0.0)$ & $5(9.1)$ & \\
Others & & & & \\
\hline Marital Status & $45(43.3)$ & $24(49.0)$ & $21(38.2)$ & 0.335 \\
Single & $56(53.8)$ & $25(51.0)$ & $31(56.4)$ & \\
Married & $2(1.9)$ & $0(0.0)$ & $2(3.6)$ & \\
Separated & $1(1.0)$ & $0(0.0)$ & & $1(0.0)$ \\
Widowed & $3(2.9)$ & $3(6.1)$ & $0(0.0)$ & 0.016 \\
\hline Education & $6(5.8)$ & $0(0.0)$ & $6(10.9)$ & \\
\hline None & $31(29.8)$ & $17(34.7)$ & $14(25.5)$ & \\
Primary & $64(61.5)$ & $29(59.2)$ & $35(63.6)$ & \\
Secondary & & & & \\
Tertiary & & & \\
\hline
\end{tabular}

\section{Data analysis}

All data of interest were analyzed using statistical package for social sciences (SPSS) version 18.0. Socio-demographic and clinical characteristics of the study participants were presented with simple descriptive statistics (including mean, mode and percentage). To compare continuous variables, Student t-test was used while the categorical variables were analyzed using chi-square test. All data of importance were represented in tables and bar chart. The $p$-values less than or equal to 0.05 were taken as significant level.

\section{Results}

One hundred and four participants with LP, 49 CLP, and 55 HLP, whose mean age was37.20 \pm 13.39 years, were enrolled into the study; there were no significant age, gender or the marital status differences among the patients having two clinical variants of LP. While most of the participants had attained at least secondary or tertiary education $(p=0.016)$, the majority of them were civil servants, traders or unemployed $(p=0.023)$ (Table 1).

Although pruritus as a symptom was insignificantly commoner in HLP, CLP patients were more likely to present with a painful rash than HLP $(p=0.046)$. The rate of treatment-seeking behavior from non-dermatologist was high (76.5\%); there was no significant difference in the treatment-seeking behavior among CLP and HLP patients. Also, tobacco smoking, alcohol intake behavior, family history of hypertension, diabetes and cardiovascular events between the two groups were not different. The CLP is more likely to be generalised (95.9\% vs $16.4 \%$, 
Table 2. Clinical Characteristics of Classic and Hypertrophic Lichen Planus

\begin{tabular}{|c|c|c|c|c|}
\hline Characteristics of Lichen Planus & Total & $\begin{array}{c}\text { Classic LP } \\
\quad \mathrm{N}=49\end{array}$ & $\begin{array}{l}\text { Hypertrophic LP } \\
\qquad \mathrm{N}=55\end{array}$ & p-value \\
\hline \multicolumn{5}{|l|}{ Clinical history } \\
\hline Pruritus & $93(89.4)$ & $41(83.7)$ & $52(94.5)$ & 0.072 \\
\hline Pain & $4(3.8)$ & $4(8.2)$ & $0(0.0)$ & 0.046 \\
\hline Previous history of lichen planus & $12(11.7)$ & $8(16.3)$ & $4(7.4)$ & 0.159 \\
\hline Sought treatment from non-dermatologist & $78(76.5)$ & $39(79.6)$ & 39 (73.6) & 0.476 \\
\hline Smoking & $4(3.8)$ & $2(4.1)$ & $2(3.6)$ & 1.000 \\
\hline Alcohol & $31(29.8)$ & $15(30.6)$ & $16(29.1)$ & 0.866 \\
\hline \multicolumn{5}{|l|}{ Family history } \\
\hline Family history of hypertension & $24(23.1)$ & $11(22.4)$ & $13(23.6)$ & 0.866 \\
\hline Family history of diabetes & $17(16.5)$ & $6(12.5)$ & $11(20.0)$ & 0.306 \\
\hline Family history of CVE & $3(2.9)$ & $3(6.1)$ & $0(0.0)$ & 0.101 \\
\hline \multicolumn{5}{|l|}{ Body Area distribution } \\
\hline Upper Limb distribution & $77(74.0)$ & $47(95.9)$ & $30(54.5)$ & $<0.001$ \\
\hline Lower Limb distribution & $101(97.1)$ & $49(100.0)$ & $52(94.5)$ & 0.097 \\
\hline Chest distribution & $21(20.2)$ & $19(38.8)$ & $2(3.6)$ & $<0.001$ \\
\hline Abdomen distribution & $29(27.9)$ & $26(52.1)$ & $3(5.5)$ & $<0.001$ \\
\hline Generalized & $56(53.8)$ & 47 (95.9) & $9(16.4)$ & $<0.001$ \\
\hline \multicolumn{5}{|c|}{ Sites of LP involvement: the skin, mucosa and nails } \\
\hline Genital Mucosa & $1(1.0)$ & $1(2.0)$ & $0(0.0)$ & 0.287 \\
\hline Oral Mucosa & 19 (18.3) & $19(38.8)$ & $0(0.0)$ & $<0.001$ \\
\hline Nail Involvement & $20(19.2)$ & $19(38.8)$ & $1(1.8)$ & $<0.001$ \\
\hline Skin and nails & $20(19.2)$ & $19(38.8)$ & $1(1.8)$ & $<0.001$ \\
\hline Skin and Oral Mucosal & 19 (18.3) & $19(38.8)$ & $0(0.0)$ & $<0.001$ \\
\hline Skin, Nail and Oral Mucosal & $11(10.6)$ & 11(22.4) & $0(0.0)$ & $<0.001$ \\
\hline \multicolumn{5}{|l|}{ Clinical Signs } \\
\hline Koebnerization & $30(28.8)$ & $27(55.1)$ & $3(5.5)$ & $<0.001$ \\
\hline Wickhiam Striae & $43(41.3)$ & $34(69.4)$ & $9(16.4)$ & $<0.001$ \\
\hline \multicolumn{5}{|c|}{ Hepatitis Screening result and Vaccination history } \\
\hline Hepatitis B vaccination & $10(9.6)$ & $8(16.3)$ & $2(3.6)$ & 0.028 \\
\hline Anti HCV positivity & $8(7.7)$ & $8(16.3)$ & $0(0.0)$ & 0.002 \\
\hline HBsAg & $5(4.8)$ & $2(4.1)$ & $3(5.5)$ & 1.000 \\
\hline \multicolumn{5}{|l|}{ Comorbid Conditions } \\
\hline Systemic Hypertension & $27(26.0)$ & $12(24.5)$ & $15(27.3)$ & 0.747 \\
\hline Diabetes Mellitus & $10(9.6)$ & $1(2.0)$ & $9(16.4)$ & 0.013 \\
\hline Dyslipidemia & $61(58.7)$ & $20(40.8)$ & $41(74.5)$ & 0.001 \\
\hline Obesity & $21(20.2)$ & $10(20.4)$ & $11(20.0)$ & 0.959 \\
\hline Metabolic Syndrome & $16(15.4)$ & $5(10.2)$ & $11(20.0)$ & 0.186 \\
\hline
\end{tabular}

CVE - Cardiovascular event like Myocardial Infarction, stroke, HCV - hepatitis C virus infection, LP - Lichen planus 
$p<0.001)$, affect the upper limbs $(95.9 \%$ vs. $54.5 \%, p<0.001)$, the upper torso: chest $(38.8 \%$ vs. $3.6 \%, p<0.001)$; abdomen $(52.1 \%$ vs. $5.5 \%)$, oral mucosa (38.8\% vs.0.0\%, p<0.001), and the nails $(38.8 \%$ vs. $1.8 \%, p<0.001)$ compared to HLP. In term of multiple involvement of body sites, CLP is more likely to significantly affect the combinations of the skin and the nails $(38.8 \%$ vs. $1.8 \%)$, skin and oral mucosa $(38.8 \%$ vs $0.0 \%, p<0.001)$ and the skin, nails and the oral mucosa $(22.4 \%$ vs $0.0 \%, p<0.001)$ compared to HLP (Table 2). Similarly, Kobner's sign (55.1\% vs. $5.5 \%, p<0.001)$ and Wickham's striae $(69.4 \%$ vs. $16.4 \%, p<0.001)$ were significantly commoner in the patients with CLP compared to those with HLP. The patients with CLP had a history of Hepatitis $B$ vaccination significantly more often ( $16.3 \%$ vs. $3.6 \%, p=0.028)$, and anti HCV positivity (16.3\% vs. $0 \%, p=0.002) \mathrm{com}-$ pared to HLP. However, diabetes mellitus (16.4\% vs. $2.0 \%, p=0.013)$ and dyslipidemia $(74.5 \%$ vs. $40.8 \%, p=0.001$ ) were more likely to be associated with HLP (Table 2).

The peculiarities of lichen planus patients (classic and hypertrophic) were examined about mucosal and nails involvement. The involvement of the mouth or the nails in CLP and HLP had no association with the patients' age, metabolic syndrome, and dyslipidemia. Those LP patients with oral mucosa and nail involvement were more likely to have upper limb onset $(p<0.001$ respectively), generalised LP $(p<0.001$ respectively), kobnerization $(p<0.001$ respectively $)$, Wickham's striae $(p=0.002$ and $p<0.001$ respectively), and clas- sic type of LP $(p<0.001$ respectively. The lower limb onset of LP is less likely to be associated with oral and nail involvement, also, localized disease is likely to be associated with no nail and mucosa involvement (Table 3).

The histologic characteristics of CLP and HLP were not different in terms of the presence of dense band of lymphocytes infiltration, vacuolar degeneration of dermo-epidermal junction, hyperkeratosis, elongation of rete ridges, melanophage, and colloid body, but the presence of saw-tooth appearance $(72.0 \%$ vs. $28.0 \%, p=0.028$ ) which was significantly associated with HLP compared to CLP (Figure 1).

The clinical pattern of the nail involvement in LP patients is shown ih Figure 2. Twenty (19.23\%) patients had nail changes. Longitudinal ridging was the most frequent pattern of nails affectation as above 18 (17.3\%), followed in that order by melanonychia $7(6.7 \%)$, nail thinning 4 (3.8\%), and pterygium 2 (1.9\%). The CLP was significantly associated with longitudinal ridging (34.7\% vs. $1.8 \%, p<0.001)$ and melanonychia (14.3\% vs. $0.0 \%, p=0.004)$ as shown in Figure 3.

\section{Discussion}

The present study shows that CLP is more likely to have upper limb onset, oral involvement, nail involvement and the presence of the eponymous signs of LP such as the Kobner's phenomenon, and Wickham's striae when compared with the HLP. The CLP is also the variant that may be associated with upper limbs, and torso distribution, HCV antibody positivity and

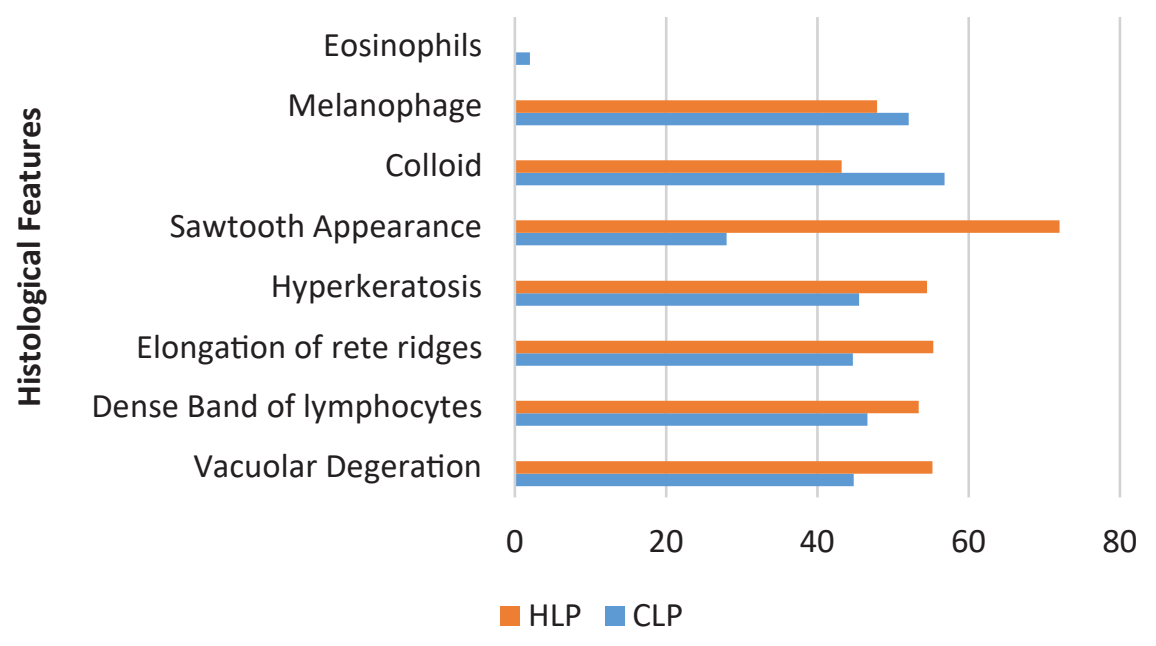

Figure 1. Histological Characteristics of Classic and Hypertrophic Lichen Planus 


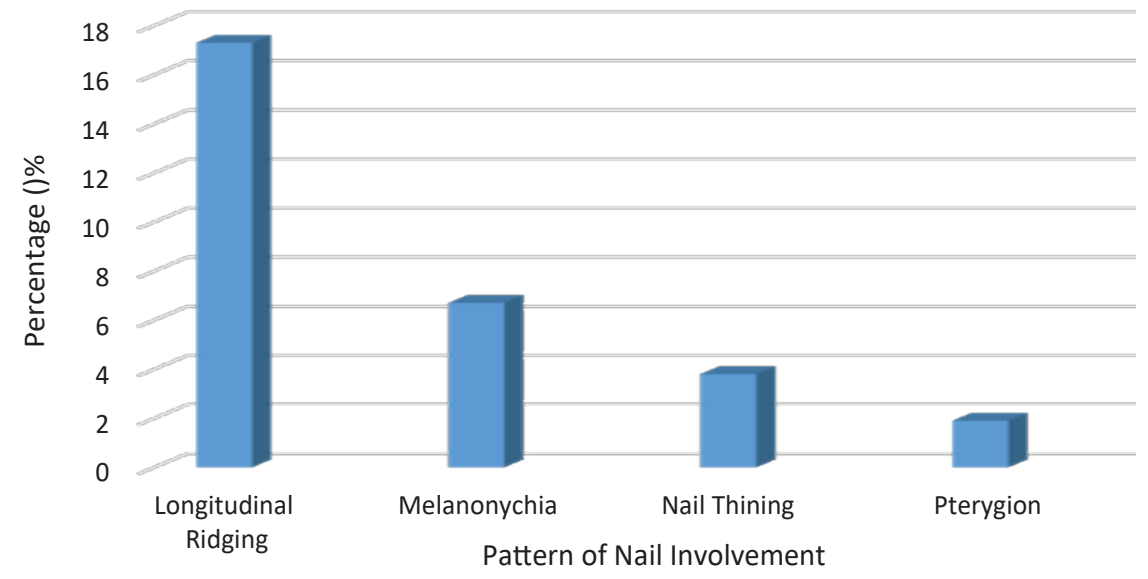

Figure 2. Pattern of Nail Involvement among Patients with Lichen Planus In Nigeria

presents as a generalized LP disease. Furthermore, the cases of HLP are more likely to originate in the lower limbs, confine to the lower legs and have a significant association with metabolic comorbidities such as diabetes mellitus and dyslipidemia compared to those with CLP.

The mean age of LP patients in the present study was $37.20 \pm 13.39$ years, that being in accordance with the previously documented adult age range of 30-60 years $(24,25)$. Similarly, the mean age of patients with LP in this study was very close to $37.13 \pm 12.8$ years as documented by Daramola et al. previously in a similar environment (15-17) and 38.8 years as documented in India by Bhattacharya et al. (26). There was no age difference between CLP and HLP patients. However, contrary to Daramola et al. (16) findings, the present study has not confirmed the female predominance of LP, as both sexes were almost equally affected by CLP and HLP. This observation is consistent with the findings of other studies as well $(25,26)$. Studies have described the CLP as a non-gender, non-racial prevalent disease with tendencies to involve the skin, nails, hair, and mucosal sites $(5,25)$. As found in the present study, limb onset of $93.2 \%$ of cases is higher than $55.6 \%$ as observed by Bhattacharya et al. (26). The CLP demonstrated tendencies to start in the upper limbs, to be widespread with the involvement of oral and nail sites (5). Nakamura et al. (27) showed that both oral mucosa and nail association in LP are manifestations of a disseminated LP disease.

Similarly, a positive antibody to HCV in the present study is significantly associated with CLP. Contrary to our finding, Daramola et al. found an increased frequency of association between HCV infection and HLP, as more than

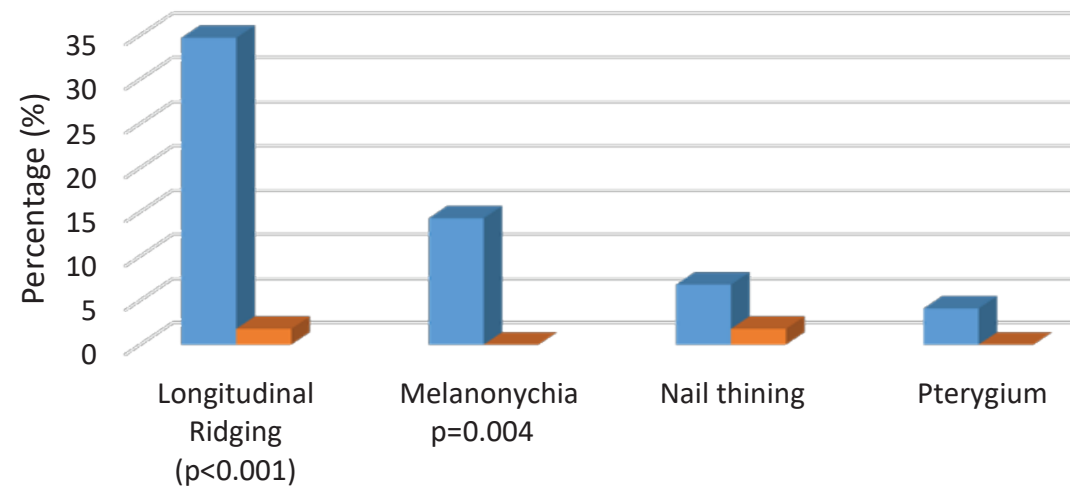

Types of Nail involvement

$\square \mathrm{CLP} \square \mathrm{HLP}$

Figure 3. Pattern of Nail involvement: Classic and Hypertrophic Lichen Planus 
Table 3. Peculiarities of lichen planus (classic and hypertrophic) in relation to mucosal and the nail involvement

\begin{tabular}{|c|c|c|c|c|c|c|c|}
\hline $\begin{array}{l}\text { Characteristics of } \\
\text { Patients }\end{array}$ & $\begin{array}{c}\text { Total } \\
N=104\end{array}$ & $\begin{array}{l}\text { Oral Mucosal } \\
\text { Involvement } \\
\text { Present } N=19\end{array}$ & $\begin{array}{l}\text { Oral Mucosal } \\
\text { Involvement } \\
\text { Absent } \mathbf{N}=\mathbf{8 5}\end{array}$ & & $\begin{array}{l}\text { LP with NailL } \\
\text { Involvement } \\
\quad \mathrm{N}=20\end{array}$ & $\begin{array}{l}\text { LP without Nail } \\
\text { Involvement } \\
\quad \mathbf{N}=\mathbf{8 4}\end{array}$ & \\
\hline Mean Age (years) \pm SD & $37.44 \pm 13.88$ & $34.10 \pm 11.45$ & $37.89 \pm 13.75$ & 0.267 & $33.55 \pm 15.46$ & $38.07 \pm 12.80$ & 0.176 \\
\hline Metabolic Syndrome & $16(15.4)$ & $1(5.3)$ & $15(17.6)$ & 0.176 & $2(10.0)$ & $14(16.7)$ & 0.458 \\
\hline Dyslipidaemia & $61(58.7)$ & $9(47.4)$ & $52(61.2)$ & 0.269 & $9(45.0)$ & $52(61.9)$ & 0.168 \\
\hline \multicolumn{8}{|l|}{ Onset of LP } \\
\hline $\begin{array}{l}\text { Predominantly Upper } \\
\text { Limb onset }\end{array}$ & $29(27.9)$ & $8(40.0)$ & $21(25.0)$ & $<0.001$ & $8(40.0)$ & $21(25.0)$ & $<0.001$ \\
\hline $\begin{array}{l}\text { Predominantly Lower limb } \\
\text { onset }\end{array}$ & $68(65.4)$ & $7(35.0)$ & $61(72.6)$ & & $7(35.0)$ & 61 (72.6) & \\
\hline Predominantly Chest & $3(2.9)$ & $3(15.0)$ & $0(0.0)$ & & $3(15.0)$ & $0(0.0)$ & \\
\hline $\begin{array}{l}\text { Predominantly Abdomen } \\
\text { onset }\end{array}$ & $4(3.8)$ & $2(10.0)$ & $2(2.4)$ & & $2(10.0)$ & $2(2.4)$ & \\
\hline \multicolumn{8}{|l|}{ Extent of Lesion } \\
\hline Localized & $38(36.5)$ & $0(0.0)$ & $38(44.7)$ & $<0.001$ & $0(0.0)$ & $38(45.2)$ & $<0.001$ \\
\hline Generalized & $66(63.4)$ & $19(100.0)$ & $47(55.3)$ & & $20(100.0)$ & $46(54.8)$ & \\
\hline \multicolumn{8}{|l|}{ Clinical Signs } \\
\hline Koebnerization & $30(28.8)$ & $13(68.4)$ & $17(20.0)$ & $<0.001$ & $15(75.0)$ & $15(17.9)$ & $<0.001$ \\
\hline Wickhiam Striae & $43(41.3)$ & $14(73.7)$ & $29(34.1)$ & 0.002 & $17(85.0)$ & $26(31.0)$ & $<0.001$ \\
\hline \multicolumn{8}{|l|}{ Type of Skin Lesions } \\
\hline Classic & $49(47.1)$ & $19(100.0)$ & $30(35.3)$ & $<0.001$ & $19(95.0)$ & $30(35.7)$ & $<0.001$ \\
\hline Hypertrophic & 55 (51.0) & $0(0.0)$ & 55 (64.7) & & $1(5.0)$ & $54(61.3)$ & \\
\hline
\end{tabular}

$77.7 \%$ of their HCV antibody positive LP patients had HLP. It must be noted that HLP was the predominant variant of LP in their study and sampling method could have accounted for the difference observed. Despite numerous published studies, the link between LP and HCV remains controversial $(16,17,28,29)$. Some researchers demonstrated a positive relationship and recommended HCV screening tests for LP patients (29, 30 ), while others did not observe such association (17). The association between LP with HCV infection appears to be dependent on geographical heterogeneity (31). A previous study has shown the increased risk of HCV positivity in LP patients (30). We found no association between HBsAg positivity and LP like the Birkenfeld et al. (30) and a history of previous immunization against HBV appears predominant among CLP patients and might explain the protection against this virus.
Hypertrophic LP is a variant of LP also known as lichen planus verrucous or lichen planus hypertrophic whose etiology is not known (5). In the present study, we found no association between HLP and the Koebner phenomenon. A study found chronic rubbing of initial lesions following intense pruritus as implicated in the development of HLP lesions from papules to verrucous or plaques (5). Similarly, some authors have suggested that eosinophils play specific unknown roles in the etiology of HLP (5, 32). In the present study, eosinophils were seen in the histology of a single case of LP, which was diagnosed as CLP. A study has described rare or no eosinophil HLP similar to CLP and plenty eosinophil HLP that resemble lichenoid drug eruption and established no significant variation in the quantity of eosinophil in biopsies about the location of the lesions (9). We found the HLP is more likely to start and localize to the 
lower limbs; this observation is in keeping with several isolated reports on HLP (8-12). The HLP involvement of the lower legs in the present study $(94.5 \%)$ is close to $88.9 \%$ described by Alomari et al. (9). Some authors have attributed venous stasis as a possible reason for the high frequency of HLP in the lower limbs $(2,26)$. It is rare for HLP to present as a widespread disease, but a report of disseminated HLP has been documented in the literature (8).

Our study found significant associations between HLP and comorbidities such as diabetes mellitus and dyslipidemia, though no significant association was found with metabolic syndrome. Previous studies have shown an association among LP, dyslipidemia and glucose intolerance (32-34). Several studies have shown chronic induction of inflammation and generation of reactive oxygen species in LP as the link among dyslipidemia, glucose intolerance, and LP (32-35). The impaired fasting and diabetes were present $(9.6 \%)$ in our study; this falls within the lower limit of 2.3-27.4\% documented in previous studies $(36,37)$. Some studies established a close association between LP and carbohydrate dysmetabolism $(36,37)$. The insulin signaling effect of the inflammatory mediators and the inflammation-induced insulin resistance may be responsible for the development of the systemic insulin-resistant state in LP patients. Apart from dysmetabolism associated with the HLP, HLP has been associated with development of squamous cell carcinoma (SCC) (10-12). A study has shown an SCC incidence of $0.27 \%$ per annum in HLP lesions, and chronic inflammation $(38,39)$ explained the association between SCC and HLP.

There is a significant association between saw-tooth histologic appearance and HLP. Saw-tooth appearance is described as profound hyperplasia of the epidermis with invagination into the dermis. The classic pseudoepitheliomatous hyperplasia described in several reports (8-12) was not seen in the present histologic review. Other features of LP including a dense band of lymphocyte infiltration, vacuolar degeneration of dermoepidermal junction, granular hyperkeratosis, and the presence of melanophages were observed but there were no differences in their occurrence in the the variants.

Concerning the presenting symptoms, we found no difference between the frequency of pruritus in the patients with CLP and HLP, although HLP had an insignificantly higher rate of pruritus compared to CLP. HLP has been documented in previous observation as the most pruritic variant $(5,25,26)$. We also observed that CLP was more associated with pain than HLP. Bhattacharya et al. also found that $19.6 \%$ of their patients with oral LP experienced burning or pain while eating hot or spicy meals (26). It is not unusual in our environment to have more than $70 \%$ of our patients to have sought help from non-orthodox sources or self-help because LP is an annoying disease with the capacity to impair quality of life.

The prevalence of nail involvement (19.23\%) is close to $15.17 \%$, as observed by Bhattacharya et al. in India. We noted that longitudinal ridging was the most frequent nail changes while pterygium was the least type pf involvement which was comparable with other published data (32). Longitudinal ridging of the nail characterizes nail involvement in LP, nail thinning, cuticular overgrowth (i. e., pterygium), atrophy of the nail bed, melanonychia, subungual keratosis, and hyperpigmentation (25).

\section{Limitation and Conclusion}

Limitations of the present study is that it is the observational single-center analysis. Also, the differences between two variants in metabolic markers and markers of chronic inflammation, thus limiting interpretation of results.

Finally, CLP is significantly associated with generalized LP disease, anti-HCV positivity, oral and nail involvement Kobner's phenomenon, and Wickham's striae. The HLP is more likely to start and be localized to the lower limbs compared to the CLP. Impaired glucose tolerance/ type 2 diabetes mellitus, dyslipidemia and histologic saw-tooth appearance were significantly associated with HLP compared to CLP. Further inferential studies are needed to elucidate the causal relationship between HLP/CLP, abnormal metabolism, and chronic inflammation.

\section{References}

1. Black MM. Lichen planus and lichenoid disorders. In: Champion RH, Burton JL, Ebling FJG, Rook AJ, Wilkinson DS. Textbook of dermatology. Vol. 3. 5th ed. Oxford: Blackwell Scientific Publications; 1992. p. 1675.

2. Boyd AS, Neldner KH. Lichen planus. J Am Acad Dermatol. 1991;25(4):593-619.

3. Usatine RP, Tinitigan M. Diagnosis and treatment of lichen planus. Am Fam Physician. 2011:84(1):53-60. 
4. Katta R. Lichen planus. Am Fam Physician. 2000;62(8): 1786. Erratum for: Am Fam Physician. 2000;61(11):331924.

5. Weston G, Payette M. Update on lichen planus and its clinical variants. Int J Womens Dermatol. 2015;1(3):140-9.

6. Lukács J, Schliemann S, Elsner P. Lichen planus and lichenoid reactions as a systemic disease. Clin Dermatol. 2015;33(5):512-9.

7. Pickert A. Concise review of lichen planus and lichenoid dermatoses. Cutis. 2012;90(3):E1-3.

8. Jaime TJ, Jaime TJ, Guaraldi Bde M, Melo DF, Jeunon T, Lerer C. Disseminated hypertrophic lichen planus: relevant response to acitretin. An Bras Dermatol. 2011;86(4 Suppl 1):S96-9.

9. Alomari A, McNiff JM. The significance of eosinophils in hypertrophic lichen planus. J Cutan Pathol. 2014;41(4): 347-52.

10. Levandoski KA, Nazarian RM, Asgari MM. Hypertrophic lichen planus mimicking squamous cell carcinoma: the importance of clinicopathologic correlation. JAAD Case Rep. 2017;3(2):151-4.

11. Totonchy MB, Leventhal JS, Ko CJ, Leffell DJ. Hypertrophic lichen planus and well-differentiated squamous cell carcinoma: a diagnostic conundrum. Dermatol Surg. 2018;44(11):1466-70.

12. Dietert JB, Rabkin MS, Joseph AK. Squamous cell carcinoma versus hypertrophic lichen planus; a difficult differential diagnosis of great significance in approach to treatment. Dermatol Surg. 2017;43(2):297-9.

13. Nnoruka EN. Lichen planus in African children: a study of 13 patients. Pediatr Dermatol. 2007:24(5):495-8.

14. Alabi GO, Akinsanya TB. Lichen planus in tropical Africa. Trop Geogr Med. 1981;33(2):143-7.

15. Daramola OO, Ogunbiyi AO, George AO. Lichen planus following hepatitis $B$ vaccination in an African girl. Trop Doct. 2002;32(2):117-8.

16. Daramola OO, Ogunbiyi AO, George AO. Evaluation of clinical types of cutaneous lichen planus in antihepatitis $C$ virus seronegative and seropositive Nigerians patients. Int J Dermatol. 2003;42(12):933-5.

17. Daramola OO, George AO, Ogunbiyi AO. Hepatitis C virus and lichen planus in Nigerians: any relationship? Int J Dermatol. 2002;41(4):217-9.

18. Trinder P. Determination of blood glucose using 4-amino phenazone as oxygen carrier acceptor. J Clin Pathol. 1969;22(2):246-50.

19. Searcy RL. Quantitative determination of triglycerides by enzymatic endpoint colorimetric method. In: Searcy RL. Diagnostic biochemistry. New York: McGraw Hill; 1969. p. 115-21.

20. Allain CC, Poon LS, Chan CS, Richmond W, Fu PC. Enzymatic determination of total serum cholesterol. Clin Chem. 1974;20(4):470-5.

21. Burstein M, Mortin R. Quantitative determination of HDL-cholesterol using the enzymatic colorimetric method. Life Sci. 1969;8:345-7.

22. Friedewald WT, Levy RJ, Fredrickson DS. Estimation of the concentration of low-density lipoprotein cho- lesterol in plasma without use of the preparative ultracentrifuge. Clin Chem. 1972;18(6):499-502.

23. Executive summary of the Third Report of The National Cholesterol Education Program (NCEP) Expert Panel on Detection, Evaluation and Treatment of High Blood Cholesterol in Adults (Adult Treatment Panel III). JAMA. 2001;285(19):2486-97.

24. Bilgili SG, Karadag AS, Ozkol HU, Calka O, Akdeniz N. The prevalence of skin diseases among the geriatric patients in eastern Turkey. J Pak Med Assoc. 2012;62(6):535-9.

25. Kyriakis KP, Terzoudi S, Palamaras I, Michailides C, Emmanuelidis S, Pagana G. Sex and age distribution of patients with lichen planus. J Eur Acad Dermatol Venereol. 2006;20(5):625-6.

26. Bhattacharya M, Kaur I, Kumar B. Lichen planus: a clinical and epidemiological study. J Dermatol. 2000; 27(9):576-82.

27. Nakamura R, Broce AA, Palencia DP, Ortiz NI, Leverone A. Dermatoscopy of nail lichen planus. Int J Dermatol. 2013;52(6):684-7.

28. Daoud MS, Gibson LE, Daoud S, el-Azhary RA. Chronic hepatitis $C$ and skin diseases: a review. Mayo Clinic Proc. 1995;70(6):559-64.

29. Jubert C, Pawlotsky JM, Pouget F, Andre C, DeForges $\mathrm{L}$, Bretagne $\mathrm{S}$, et al. Lichen planus and hepatitis $\mathrm{C}$ virusrelated chronic active hepatitis. Arch Dermatol. 1994;130(1):73-6.

30. Birkenfeld S, Dreiher J, Weitzman D, Cohen AD. A study on the association with hepatitis $B$ and hepatitis $C$ in 1557 patients with lichen planus. J Eur Acad Dermatol Venereol. 2011;25(4):436-40.

31. Song J, Zhang Z, Ji X, Su S, Liu X, Xu S, et al. Lack of evidence of hepatitis in patients with oral lichen planus in China: a case-control study. Med Oral Patol Oral Cir Bucal. 2016;21(2):e161-8.

32. Arias-Santiago S, Buendía-Eisman A, Aneiros-Fernández J, Girón-Prieto MS, Gutiérrez-Salmerón MT, Mellado VG, et al. Cardiovascular risk factors in patients with lichen planus. Am J Med. 2011;124(6):543-8.

33. Arias-Santiago S, Buendía-Eisman A, Aneiros-Fernández J, Girón-Prieto MS, Gutiérrez-Salmerón MT, GarcıaMellado V, et al. Lipid levels in patients with lichen planus: a case-control study. J Eur Acad Dermatol Venereol. 2011;25(12):1398-401.

34. Seyhan M, Ozcan H, Sahin I, Bayram N, Karincaoğlu Y. High prevalence of glucose metabolism disturbance in patients with lichen planus. Diabetes Res Clin Pract. 2007;77(2):198-202.

35. Lu R, Zhang J, Sun W, Du G, Zhou G. Inflammation-related cytokines in oral lichen planus: an overview. J Oral Pathol Med. 2015;44(1):1-14.

36. Petrou-Amerikanou C, Markopoulos AK, Belazi M, Karamitsos D, Papanayotou P. Prevalence of oral lichen planus in diabetes mellitus according to the type of diabetes. Oral Dis. 1998;4(1):37-40.

37. Romero MA, Seoane J, Varela-Centelles P, Diz-Dios P, Garcia-Pola MJ. Prevalence of diabetes mellitus amongst 
oral lichen planus patients. Clinical and pathological characteristics. Med Oral. 2002;7(2):121-9.

38. Mehta NN, McGillicuddy FC, Anderson PD, Hinkle CC, Shah R, Pruscino L, et al. Experimental endotoxemia induces adipose inflammation and insulin resistance in humans. Diabetes. 2010;59(1):172-81.
39. Krasowska D, Kozłowicz K, Kowal M, Kurylcio A, Budzyńska-Włodarczyk J, Polkowski W, et al. Twice malignant transformation of hypertrophic lichen planus. Ann Agric Environ Med. 2012;19(4):787-9.

\section{Epidemiološke i kliničke razlike između klasičnog i hipertrofičnog lihena planus u Nigeriji}

\section{Sažetak}

Uvod. Lihen planus je inflamatorno oboljenje kože sa nekoliko kliničkih varijanti i različitim kliničkim ishodima. Primećene su neke komplikacije kod hipertofičnog tipa koje se ne nalaze kod klasične varijante. Cilj je bio da se ustanove epidemiološke i kliničke razlike između klasičnog i hipertrofičnog lihena planus i kliničke povezanosti. Materijal i metode. Od 104 ispitanika sa lihenom planus, 49 su imali klasični a 55 hipertrofični lihen planus. Skupljeni su demografski i klinički podaci. Lihen planus je dijagnostikovan klinički i potvrđen histološki. Ispitanici su pregledani na metabolički sindrom, hepatitis B i C. Rezultati. Prosečna životna dob svih pacijenata bila je $37,20 \pm 13,39$ godina, bez starosnih i polnih razlika između ispitanika sa klasičnim i hipertrofičnim lihenom planus. Klasični lihen planus je češće bi bolan (8,2\% vs
$0,0, p=0,046)$, generalizovan (95,9\% vs $16,4 \%, p<0,001)$, obuhvatao je usnu duplju (38,8\% vs $0,0, p<0,001)$, nokte ( $38,8 \%$ vs $1,8, p<0.001)$, bio povezan sa vakcinom protiv hepatitisa B $(16,3 \%$ vs $3.6 \%, p<0,028)$ i anti-HCV pozitivnosti $(16,3 \%$ vs $0,0 \%, p=0,002)$. Hipertrofični lihen planus je bio značajno povezan sa poremećenom tolerancijom glukoze (16,4\% vs $2,0 \%, p=0,013)$, dislipidemijom $(74,5 \%$ vs $40,8 \%, p=0,001)$ i nazubljenim invaginacijama epiderma u derm na histologiji u poređenju sa klasičnim tipom. Zaključak. Hipertrofični lihen planus je uglavnom povezan sa metaboličkim komplikacijama za razliku od klasičnog tipa. Potrebno je izvesti dodatna istraživanja da se poveže ova razlika sa hroničnom inflamacijom.

Ključne reči: Lichen planus; Komorbiditet; Znaci i simptomi; Oralni lichen planus; Dijabetes melitus; Dijagnoza; Epidemiološke studije; Nigerija

Received 5.03.2019.

Accepted 9.07.2019. 